\title{
СИМВОЛИЗМ В ТВОРЧЕСТВЕ ВИКТОРА ЭЛЬПИДИФОРОВИЧА БОРИСОВА-МУСАТОВА
}

\begin{abstract}
Аннотация. В статье представлены особенности творчества Саратовского художника, Виктора Эльпидифоровича Борисова-Мусатова. Стремление достичь особой интенсивности, духовности, реализма и пластичности в своих работах. В качестве примера рассмотрены несколько работ и проведены параллели с основателем и певцом русского символизма М. А. Врубеля. Цель: Рассмотреть и изучить творчество Саратовского художника Виктора Эльпидифоровича Борисова-Мусатова, сделать анализ его работ. Выявить их общие черты. Метод: Подробный анализ работ В. Э. БорисоваМусатова и других русских художников-символистов, выявление схожих и различных черт. Результат: В. Э. Борисов - Мусатов внес огромный вклад в развитие русского символизма. Перенимая врубелевский опыт, он продолжает развивать символистку линию в русской живописи.
\end{abstract}

Ключевые слова: Саратов, искусство, Русский символизм, Саратовская школа живописи, живописцы-символисты.

O.S. Borisova, O.I. Guzenina

The DOD "Children's art school", Saratov, Russia

E-mail: yaryginao@mail.ru

\section{SYMBOLISM IN THE WORKS OF VICTOR ELPIDIFOROVICH BORISOV-MUSATOV}

\begin{abstract}
The article presents the features of the work of the Saratov artist, Victor Elpidiforovich Borisov-Musatov. Striving to achieve special intensity, spirituality, realism and plasticity in his works. As an example, several works are considered and Parallels with the founder and singer of Russian symbolism M. A. Vrubel are drawn. Purpose: to Consider and study the work of Saratov artist Viktor Borisov-Musatov, to analyze his works. Reveal their common traits. Method: a Detailed analysis of the works Of V. E. Borisov-Musatov and other Russian symbolist artists, identifying similar and different features. Result: V. E. BorisovMusatov made a huge contribution to the development of Russian symbolism. Adopting Vrubel's experience, he continues to develop the symbolist line in Russian painting. painters.

Keywords: Saratov, art, Russian symbolism, Saratov school of painting, symbolist

История изобразительного искусства Саратова тесно связана с историей Радищевского музея. Во многом благодаря открытию в Саратове этого музея, появилась блистательная плеяда мастеров совсем не провинциального масштаба - Виктор Борисов-Мусатов, Кузьма Петров-Водкин, Пётр Уткин, Павел Кузнецов и другие. Их творчество оказало огромное влияние на последующие поколения саратовских художников.
\end{abstract}

Одной из основных линий развития саратовского изобразительного искусства является декоративный символизм, который берёт начало в творчестве Виктора Эльпидифоровича Борисова-Мусатова и впоследствии 
получит продолжение в художественной практике мастеров «саратовской школы живописи».

Цель: Рассмотреть и изучить творчество Саратовского художника Виктора Эльпидифоровича Борисова-Мусатова. Рассмотреть его знаменитые полотна, сделать анализ его работ. Выявить их общие черты.

Предмет: Символизм в живописи В. Э. Борисова-Мусатова

Объект: Особенности символистской живописи Саратовского художника В. Э. Борисова-Мусатова.

Виктор Эльпидифорович Борисов-Мусатов ( 1870 - 1905) - русский художник, живописец, мастер символических изображений.

Виктор Борисов-Мусатов родился в Саратове. Первоначальные свои знания и навыки рисования получил от преподавателя рисования Ф. А. Васильева. В 1890-х учился изобразительному искусству в студии Саратовского общества изящных искусств, после чего, в Московском училище живописи, ваяния и зодчества и в Санкт-Петербургской Академии художеств. Учителем В. Э. Борисова-Мусатова был Павел Петрович Чистяков. Художник разделял взгляды художественного объединения «Мир искусства». В 1895 году путешествовал по Крыму и Кавказу. БорисовМусатов вступает в Союз русских художников. [1, с.22].

С 1898 год жил в основном в Саратове, с 1901 года - в имении Зубриловка Саратовской губернии. Уже тогда усадьба пребывала в запустении, редко посещаемая тогдашними хозяевами. В 1902 году БорисовМусатов вновь посетил усадьбу вместе с сестрой Еленой и художницей Еленой Владимировной Александровой — будущей женой.

Борисов-Мусатов являлся членом «Саратовской школь жсивописи». Все художники этого объединения были символистами. Символизм направление, восстающее в первую очередь против прямолинейного позитивизма и эмпиризма второй половины XIX века. Цель символизма в поэзии, музыке, живописи - познать «подлинные сущности» предметов и явлений интуитивным путем.

Вместе с тем символизму была в известной мере свойственна романтическая жажда разрушения или, скорее, преодоления буржуазных стандартов, отвращение к прозе буржуазного мира.

Как и большинство направлений искусства и литературы конца столетия, символизм в России возникает несколько позднее, но развивается быстрее и интенсивнее, чем на Западе и является заключительным звеном его взлета.

Русские живописцы-символисты не имели непосредственных предшественников в отечественном искусстве. Романтизм в русской 
живописи XIX века, оказавшийся течением достаточно узким, не имел развития и продолжения, будучи оттеснен и подавлен мощным потоком реалистической живописи критического направления, получившим законченное выражение в передвижничестве. Влияние же творчества Александра Иванова, гениального, хотя и не высказавшегося до конца мастера середины XIX века, с его философией нравственного очищения через искусство и попытками соединить принципы классицизма с пленэрной живописью, начало ощущаться только в восьмидесятые годы - прежде всего, в искусстве Врубеля. [2].

Однако предпосылки к возникновению символистских тенденций в русской живописи были, и заключались они в особенностях уже упоминавшийся общей ситуации общественной и культурной жизни России последней трети века. К середине восьмидесятых годов в русском искусстве сложилось достаточно напряженное положение. Если в предыдущие полторадва десятилетия друг другу противостояли два основных направления, две весьма мощные группировки - передвижники, носители особого вида реализма критического, обличавшего социальную и общественную несправедливость, и искусство академическое, часто салонно-академическое, застывшее и в своих содержательных, и в формальных характеристиках, то теперь соотношение сил меняется. В самой среде передвижников, сумевших добиться уже к середине семидесятых годов огромной популярности, бывших в известной мере живописным «рупором» народников, начинают появляться признаки разочарования в прежних идеалах, влекущие за собой и все нарастающее расслоение. Возникают связи между старшими передвижниками и их недавним врагом - официальным искусством Академии художеств (что привело в 1894 году к реформе преподавания в Академии и вхождению в число ее профессоров ряда крупных передвижников, в том числе Ильи Репина). С другой стороны, все сильнее становится оппозиция основным тенденциям живописной системы передвижников со стороны воспитанных под их эгидой молодых живописцев. [3, с.30].

Постепенно образуется круг художников, которые к середине девяностых годов займут ведущее положение в русской живописи и определят ее значимость и характер. К этому кругу принадлежат такие мастера, как Михаил Врубель, Валентин Серов, Исаак Левитан, Константин Коровин, Михаил Нестеров, Александр Головин, Аполлинарий Васнецов, Сергей Малютин, Елена Поленова, Мария Якунчикова. Большинство из них москвичи, объединившиеся в так называемый Абрамцевский кружок, во главе которого стоял меценат (а вернее друг художников), талантливый дилетант и блестящий организатор множества начинаний в области русского искусства Савва Мамонтов. Пройдет несколько лет, и весьма видное место в культуре рубежа веков займут молодые петербуржцы - члены «Мира искусства» во главе с крупнейшим в будущем художественным деятелем Сергеем Дягилевым и Александром Бенуа. Константин Сомов, Лев Бакст, Анна Остроумова, Евгений Лансере, Мстислав Добужинский В это же время 
выхолят на сцену и такие разные живописцы, как Алексей Рябушкин, Филипп Малявин, Николай Рерих и Виктор Борисов-Мусатов, сыгравший огромную роль в становлении русского символизма. Однако здесь возникает некий парадокс, характерный для русской культуры этих десятилетий вообще. Общее направление живописных поисков конца века, на первый взгляд, кажется достаточно единым. Молодые мастера, стремясь к обновлению искусства, к одухотворению его интенсивным чувством, к выработке гибкого и выразительного живописного языка, не посягали еще в ту пору на основы реалистического метода второй половины XIX века. Они его обогащали. [4, с.101-108].

Отцом и зачинателем русского символизма принято считать Владимира Соловьева, не только и не столько поэта (к тому же порою зло пародировавшего символистскую поэзию), сколько философа-неоплатоника.

Нигде в Европе не было такой напряженной экономической, политической, общественной ситуации, как в России конца XIX века. Это время интенсивного промышленного развития страны, роста городов и одновременно пора глубокого разочарования русской интеллигенции в вульгарном материализме и эмпирической раздробленности науки XIX века. Это время подготовки плацдарма для битв нового со старым во всех областях русской жизни. [5, с.70-74]. В сфере русской культуры - нарастание столкновений, взаимных притяжений и отталкиваний, идеологического размежевания ранее сплоченных группировок и переплетения, казалось бы, взаимоисключающих явлений.

Русские символисть - стремились к совершенно уникальной, интенсивной духовности, усваивали и уроки реализма, в его совершенно новой, импрессионистической ипостаси, и уже полюбившегося модерна, трудились над выработкой художественного языка, наиболее адекватного символистскому содержанию их искусства, сдержанно-ностальгическому или трагедийному - в зависимости от личностных качеств и творческого темперамента. Русских живописиев-символистов можно разделить с не меньшим основанием, чем символистов-литераторов, на «старших» и «младших». К первым следует отнести, основываясь на семантике и стилистике их искусства, Врубеля, мирискусников, Рериха. Ко вторым Борисова-Мусатова, положение которого в известной мере было все же промежуточным (и напоминало тем самым положение Брюсова), мастеров «Голубой розы» во главе с Павлом Кузнецовым и, конечно, ПетроваВодкина. [6, с.119-125].

В. Э. Борисов - Мусатов внес огромный вклад в развитие русского символизма.

Он продолжал врубелевскую символистскую линию в русской живописи. Опыт этого художника дает повод для прямых сопоставлений. Та гомогенность мира, которую открывает родоначальник русского символизма, 
выражает скорее трагическую жажду апокалипсиса, не подкрепленную верой в торжество Божественного света, чем стремление к одухотворению материи, вольно или невольно воплощенное в мусатовской концепции единства и однородности мира. Это сопоставление вовсе не означает того, что врубелевскому неверию противостоит вера Мусатова. Но дело не в их противоположности. И Врубель и Мусатов вырабатывали каждый свой канон живописной материи. [7, с.89-96]. И у того и у другого живописный атом, из комбинации которых создается постройка, это как бы некая секуляризованная, оторвавшаяся от христианской основы параллель тому «веществу мира», какое сосредоточено в евхаристических дарах и связано со всем «мировым веществом». И Врубелю и Мусатову эта идея единства мира могла достаться не как задача, продиктованная ниспосланным свыше озарением, а как продукт памяти человечества, памяти культуры, наконец, живописи.

Гармония, которую некогда искал Мусатов, приобрела совершенно особый характер и открывала определенную, далеко идущую в даль перспективу. Это была гармония трудная. Трудность гармонии стала предметом еще одной важной метафоры. Речь идет о затрудненности движения фигур и бытия предметов в окружающей среде. Их однородность не имеет в виду взаимопроникновение и бесконфликтное сосуществование. Начиная с его знаменитых «Мальчиков» 90-х годов - особенно с «Мальчика с кувшином», здесь наблюдается явное намерение художника наградить фигуры и предметы своеобразной интенцией самоутверждения. Это намерение было связано с выходом из системы импрессионизма, но затем приобрело другой смысл.

В зрелых работах Мусатова фигуры преодолевают сопротивление какихто невидимых сдерживающих их сил. Нельзя сказать, что эти силы заключены только в данном пространстве. Естественно - это пространство застыло, оцепенело, оно околдовано какой-то сверхъестественной незримой немотой и неподвижностью. Но вместе с тем сдерживающее начало заложено и в самих фигурах. Их позы и жесты редко объяснимы внешней событийностью. Их движения слишком медленны, пластичные, затруднены; в них чувствуется усилие преодоления. Но художник фиксирует не столь процесс преодоления, сколь результат - преодоленность. Особенно определенно эта тенденция проступает в «Гобелене», где левая женская фигура, с трудом наклонявшаяся, наконец завершила этот процесс и довела движение до конечной фазы. А правая с трудом повернула голову и тоже зафиксировала этим поворотом исчерпанность движения. [8].

Затрудненность движения является одной из главных пластических тем Мусатова. Его герои с усилием меняют позы, иногда застывают в трудных положениях, в момент пробуждения, духовного перелома или погружения в $\mathrm{coH}$. 
Самым опасным и разрушительным представляется прием, примененный в «Изумрудном ожерелье». Полное отсутствие линии горизонта делает нас участниками происходящего на полотне. Изобилие разнообразных зеленых красок придают картине ощущение пространства и воздуха. Участницы полотна не смотрят на зрителя, что вносит на полотно элемент таинственности. Девушки на полотне безмолвствуют, но у зрителя складывается несколько иное впечатление, так как героини встречаются взглядами, едва улыбаются, словно мгновение назад они вели неспешную беседу. Фигура рыжеволосой женщины в какой-то странной позе, ничем не оправданной сюжетно, наклонившись, словно падая, готова перешагнуть через край и оказаться за пределами картинной плоскости. Но и здесь неустойчивость нейтрализована и гармония восстановлена. Центральная фигура развернута в противоположную сторону, она сдерживает рискованное движение. Его останавливает также свободное пространство между участниками этой сцены, которое остается за спиной большей части процессии, не давая ей скатиться за раму. Взгляды уравновешены в их противонаправленности. Пластический и смысловой конфликт сохраняется, но гармония оказывается восстановленной.

Возможно подобные или близкие приемы нейтрализации конфликта и «наведения порядка» можно встретить в классической живописи более раннего времени. Но нельзя недооценивать того обстоятельства, что в творчестве Борисова-Мусатова эта проблема превращается в едва ли не обязательную. Ее навязчивость не случайна. Анализ работ художника позволяет говорить о новом понимании гармонии, которая стала предметом искания художников новых поколений.

Символисты следующего поколения выработали другой метод, который можно обозначить как обобщение до символа. Это можно видеть в работах мастеров русского объединения художников-символистов «Голубая роза».

Символизм в русской живописи развивался в творчестве ряда русских художников. Главной задачей символизма являлось установление связей конкретных, видимых явлений с идеальными представлениями, с незримой реальностью. Символом может быть любой знак, предмет. Символисты любого направления предавали особое значение слову «Греза», в котором едва слышны далекие отголоски субъективного опыта, которым осознанно заряжает свою грезу символист.

Вклад, который внесенный в развитие русского символизма В. Э. Борисовым - Мусатовым огромен. Он продолжал врубелевскую символистскую линию в русской живописи. Врубелевский опыт дает повод для прямых сопоставлений. Та гомогенность мира, которую открывает родоначальник русского символизма, выражает скорее трагическую жажду апокалипсиса, не подкрепленную верой в торжество Божественного света, 
чем стремление к одухотворению материи, вольно или невольно воплощенное в мусатовской концепции единства и однородности мира.

Список использованной литературы и источников:

1. Бульчев М.В., Максимов Е.К. Четыре века: сборник статей, посвященный 400летию Саратова. Саратов: Издательство Саратовского университета, 1991. 208c.

2. Биография и творчество художника/ Artonline.ru [Электр. ресурс].- Режим доступа: https://allpainters.ru/borisov-musatov-viktor.html

3. История русского и советского искусства: Учеб. пособие для вузов. М.: «Высшая школа», 1989. 407c.

4. Сарабьянов Д.И. История русского искусства конца 19-начала 20 века. М.: «Галарт», М: 2001. 301c.

5. Русакова А.А. Автор вступительной статьи и составитель альбома Борисов Мусатов. М.: «Аврора»,1975. 407с

6. Водонос Е.И. Выдающиеся мастера «Саратовской школы» в зеркале художественной критики. Саратов, 2003. 288c.

7. Беда Г.В. Живопись М.: «Просвещение», 1986. 192с.

8. Просто красивая эпоха: Виктор Эльпидифорович Борисов-Мусатов/ Artonline.ru [Электр. pecypc].- Режим доступа https://www.pravmir.ru/prosto-krasivaya-epoxaviktor-elpidiforovich-borisov-musatov/ 